\title{
INSIDE THE DYNAMICS OF INDUSTRIAL CAPITALISM: THE MASS PRODUCTION OF CARS IN SPAIN, 1950-1985*
}

\author{
TOMÀS FERNÁNDEZ-DE-SEVILLA
}

Universitat de Barcelona ${ }^{\mathrm{a}}$

\begin{abstract}
In 2010 Spain ranked second among EU-15 countries in the manufacture of passenger cars; however, in 1950 the country's car production had been purely symbolic. Taking as its starting point the trajectories of the enterprises that have shaped the auto industry in Spain, this study explores the sector's process of development within the interpretative framework proposed by Alfred D. Chandler in Scale and Scope. Until the mid-1970s, SEAT and FASA-Renault, the sector's first-movers, maintained their position as industry leaders. The entry of Ford and GM in the 1970s was to restructure the industry as it shifted its focus towards exportation to the European Economic Community. Both market share and net profits are used as indicators of the evolution of each car maker.
\end{abstract}

Keywords: automobile, industry, Spain, development, Chandler

JEL classification: N64, N84, O25

\footnotetext{
* Received 18 October 2013. Accepted 26 March 2014. This article forms part of the project HAR2012-33298, directed by Jordi Catalan, to whom this paper owes a great deal. Acknowledgements are also offered to the anonymous referees and the editors of the journal. Financial support from the Centre d'Estudis Antoni de Capmany, directed by Carles Sudrià, is gratefully acknowledged. The usual disclaimers apply.

a Centre d'Estudis Antoni de Capmany, Universitat de Barcelona, Av. Diagonal 690, 08034, Barcelona, Spain. tomasfernandezdesevilla@ub.edu
} 


\section{RESUMEN}

En 2010 España figuró en el segundo puesto en producción de automóviles de turismo entre los países de la UE-15. No obstante, en 1950 la producción de coches era puramente testimonial. Siguiendo el marco interpretativo propuesto por Alfred D. Chandler en Scale and Scope, el trabajo explora el proceso de desarrollo de esta industria a partir de las trayectorias de las distintas empresas. Hasta mediados de los setenta, SEAT y FASA-Renault, definidas como first-movers, mantuvieron su posición como líderes del sector. La entrada de Ford y GM alteró la estructura de la industria, que se orientó hacia la exportación a la CEE. La cuota de mercado y los beneficios netos se utilizan como indicadores de la evolución de cada fabricante.

Palabras clave: Automóvil, Industria, España, Desarrollo, Chandler

\section{INTRODUCTION}

Scale and Scope represents the culmination of the research conducted by Alfred D. Chandler Jr. into the emergence and growth of large-scale enterprise and Chandler's work remains one of the most powerful and thought-provoking explorations of economic and business history to appear in the last half-century ${ }^{1}$. In this work, Chandler tests his initial hypotheses about the determinants of success for the large-scale enterprise as an institution in the United States by undertaking a comparative analysis with Great Britain and Germany (see Chandler 1962, 1977). On the strength of empirical evidence obtained from the study of the 200 largest industrial firms in each country, Chandler describes three models of capitalism articulated in terms of large-scale enterprise: competitive managerial capitalism, characteristic of the United States; personal capitalism, predominant in Great Britain; and finally, cooperative capitalism, typical of Germany. Precisely because his research is limited in time to the period between the $1880 \mathrm{~s}$ and the mid- $20^{\text {th }}$ century and focuses only on the three countries mentioned, Chandler concludes his work with a call for further case studies to validate or refute his thesis «industry-by-industry, country-by-country» (Chandler 1990, p. 628). Picking up the gauntlet thrown down by Chandler, the aim of this paper is to place the development of Spain's car industry within Chandler's explanatory model of dynamic change in industrial capitalism ${ }^{2}$.

In Scale and Scope, Chandler explains that the success of the second industrial revolution can be attributed to the potential to exploit the cost advantages

\footnotetext{
1 Chandler's work still provokes great debate among leading economic historians, including Scranton (1997), Amatori (1997), Wilkins (2008) and Foreman-Peck and Hannah (2012).

2 An overview of the history of the firm in Spain can be found in Comín and Martín Aceña (1996) and Valdaliso and López (2000).
} 
of the economies of scale and scope derived from the new capital-intensive production technologies. A three-pronged investment was mandatory to maximise these potential cost advantages: investment in production facilities to exploit a technology's potential economies of scale and scope; investment in marketing and the distribution network - to sell the increased production volume; and investment in management and organisation - to coordinate and monitor basic functional activities, and to plan and allocate resources for future production and distribution. The large firms that managed to exploit the economies of scale fully enjoyed an impressive cost advantage over the rest. The three-pronged investments made by the first-movers raised a high barrier to entry for the latecomers. The pioneers were able to maintain their market share because their net profits, which permitted them a level of investment that the challengers could not match. However, market share could only be maintained if the managerial organisation evolved its functional capabilities and adjusted its strategies according to constantly changing market and technological opportunities. By building a coherent managerial structure, companies were able to compete both functionally (developing more efficient processes of production and distribution, new and differentiated products and better marketing services) and strategically (moving into growing markets more rapidly and out of declining ones more quickly). Their efficiency was thus revealed by their ability to maintain market share and profit levels.

The proposals made in Scale and Scope obtained an immediate response. As well as a number of important criticisms, the book gave rise to numerous studies that adhered to the agenda proposed ${ }^{3}$. In relation to the Spanish case, the most notable contribution was the study published by Albert Carreras and Xavier Tafunell (1997) within the book edited by Chandler himself, together with Franco Amatori and Takashi Hikino, which offered an international and comparative perspective of Chandler's ideas. The Spanish case study provides an analysis of the evolution of the 200 largest Spanish firms measured in terms of their assets between 1917 and 1990, employing six benchmarks. Two of the findings presented are of significance for the discussion undertaken in this article. First, the period of greatest growth for Spain's large firms comprised the years between 1960 and 1974; and, second, in 1974 car makers were predominant among the country's largest manufacturing firms, with SEAT (sixth), Ford España (eighth), FASA-Renault (thirteenth) and Chrysler España (fourteenth) ranked within the top fifteen. In addition, based on an aggregate analysis of Spain's 100 largest nonfinancial corporations in terms of sales in 1973 and 2002 and in terms of assets in 1950, Veronica Binda (2012, pp. 522-523) reports that these firms shaped their strategies and structures based not solely on economic facts, but also in relation to the political and social context, pointing to the importance of such factors as delayed industrialisation and state intervention.

${ }^{3}$ On criticism, see, for example, Supple (1991) and Hannah (1995). 
While the exploitation of large databases of different benchmarks constituted one of the pillars on which Chandler based his proposals, the other was his extraordinary factual rigour, derived from exhaustive historical case studies. The aim of this study is therefore to participate in the debate on the dynamics of industrial capitalism by analysing the process of development of the automotive industry in Spain. In his pioneering book Concept of the Corporation, Peter Drucker (1946) defined the automotive industry as "the industry of industries» (cited in Womack et al. 1990, p. 9). And he was not mistaken. Car manufacturing became a strategic factor of the first order in the promotion of industrialisation in the developing countries. When Drucker made his assessment, the manufacture of passenger cars in Spain was purely symbolic. The absence of one of the most characteristic industries of the second industrial revolution complicated the industrialisation of the Iberian Peninsula. Nonetheless, by the outset of the $21^{\text {st }}$ century, turnover in the sector (including parts and components) represented roughly 5 per cent of Spanish GDP and 20 per cent of total exports. The sector's balance of trade was clearly positive and twelve of the thirty largescale exporters in Spain operated in the sector (Asociación Nacional de Fabricantes de Automóbiles y Caminones (ANFAC), 1990-2010). These data point to the automotive industry as one of the chief driving forces of the Spanish economy.

Studies by Jordi Catalan (2000) and José L. García Ruiz (2001) represent the first academic analyses of the trajectory of the automotive industry in Spain. Among the general factors behind the industry's development, Catalan (2000, pp. 136-137) points to the prominence of proactive strategic policies (protection, limited investment licences and local content requirements), the positive response of the Spanish manufacturing base (which reaped benefits from the presence of externalities arising out of the Marshallian industrial districts) and the success of business initiatives such as SEAT and FASA-Renault. Catalan (2000, pp. 145-146), taking a view that is, broadly speaking, shared by García Ruiz (2001, p. 154) places the emphasis on the abrupt shift in industrial policy that occurred in 1972 with the enactment of the so-called Ford decrees. From that moment onwards, the leitmotif of industrial policy focused on the attraction of the U.S. giants and integration in the European Economic Community (EEC). This new direction entailed the gradual dismantling of protectionism and the discontinuation of preferential support for the state-owned enterprise SEAT, which was plunged into a serious crisis. With these changes, the industry's source of growth shifted towards exportation to the EEC ${ }^{4}$.

However, when these studies appeared, our historical understanding of the individual development of the enterprises shaping Spain's automotive

\footnotetext{
${ }^{4}$ Catalan revisits these conclusions in Catalan (2010) and Catalan and Fernández-de-Sevilla (2013).
} 
industry was still in a very early stage. For this reason, their publication spurred the appearance of a number of studies addressing the main companies in the sector. By applying a business historical lens to a qualitative aggregation of these studies, we aim to further our knowledge of the passenger car industry in line with both the analytical framework and the empirical strategies defined by Chandler. Adhering to his claim that «Price remained a significant competitive weapon, but these firms competed more forcefully for market share and increased profits by means of functional and strategic efficiency» (Chandler 1990, p. 36), this paper uses both the market share in Spain and net profits as indicators of the evolution of each car maker.

Section 2 starts with an examination of the main initiatives predating the creation of SEAT and FASA, the two firms identified as first-movers. It then addresses the creation of these two firms and their subsequent development. This is followed, in Section 3, by a description of business initiatives that sought to challenge the dominant position of SEAT and FASA during the 1960s. The penultimate section explores the consequences of the shift in industrial policy in the 1970s, and the final section shows the process of sector restructuring. The study concludes with Spain's new membership of the EEC. By that time, the Spanish passenger car industry was already a mature sector. Aggregate production stood at the same level in Spain as in Italy and it had outstripped Great Britain. In addition, the industry's export percentage was greater than 50 per cent of units produced.

Chandler (1992) argues that the focus on the accumulation of firm-specific capabilities provides an analytical framework in which to situate studies of the evolutionary nature of large industrial enterprises. These organisational capabilities, derived from competitive struggle, become the basis for their continuing growth. In analysing the evolution of existing industries, the firm would seem to be a useful unit of analysis. Such research requires a consideration of the way in which each enterprise develops its organisational capabilities and how this is reflected in their long-term competitive strengths and weaknesses. As the following sections in this article show, in the case of the car industry in Spain, the ability to control and pull the strings of government became one of the industry's core competencies. Two firms that produced their first cars in 1953, SEAT and FASA, were to establish themselves as first-movers. In the 1950s and 1960s the dominant position of these two firms was still open to challenge. At the business level, the reconfiguration of the sector only became possible with a change in the direction of industrial policy in the early 1970s when a new legal framework opened the doors to Ford and GM. The presence of these U.S. giants substantially altered the business structure of the sector, which was pushed definitively into the dynamics of large-scale transnational firms, participating fully in the international division of labour that they proposed. 


\section{THE TAKEOFF OF THE FIRST-MOVERS}

In Spain, the first recorded experience of automobile construction took place in 1889, when Francesc Bonet patented a tricycle powered by the combustion engine in Barcelona. During the first third of the $20^{\text {th }}$ century, some forty initiatives in the Catalan capital and a further ten outside Catalonia followed Bonet's pioneering work. Of these, Hispano-Suiza, which was also founded in Barcelona by a group of capitalists led by Damià Mateu but in 1904, stands out. The impressive results obtained by the Swiss engineer Markus Birkigt rapidly gained the company an excellent reputation not only on the peninsula but also in Europe. However, the company's potential was limited by the orientation of its activity towards luxury models at the expense of mass production. By the end of the 1920s, Hispano-Suiza's modest production figures - about 1,000 passenger cars, 500 trucks and 600 aircraft engines per year - left the company lagging far behind the leading European firms ${ }^{5}$.

In those years, the Spanish market was dominated by Ford, while local manufacturers had negligible market shares. From 1923, the U.S. giant had operations in Barcelona. As a result of the depression of 1929, the U.S. automaker transferred 40 per cent of the capital in their subsidiary to local shareholders and the subsidiary was renamed Ford Motor Ibérica (Estapé 1998). Finally, the victory of General Franco's rebel forces in the Spanish Civil War of 1936-1939 cut short the company's development. In the early years of the Franco dictatorship, industrial policy had many points in common with the industrial policy applied in Nazi Germany. In the year of its victory, the insurgent government enacted a law covering the organisation and defence of industry, taking the view that industry was «parte integrante del Patrimonio Nacional y subordinada al interés supremo de la Nación» and proclaiming that «no podrán instalarse nuevas industrias, traslados ni ampliar las existentes, sin la resolución favorable del Ministerio de Industria y Comercio»(Boletin Oficial del Estado [BOE], 15 December 1939).

In the automotive sector, the inspiration taken by the new regime from the Axis powers and the strictly discretionary nature of its decisions were both strongly felt. Ford became the subject of blatant discrimination and finally abandoned its subsidiary in $1953^{6}$. For its part, GM's proposal to set up in Spain, which happened in 1939 immediately on conclusion of the Civil War, received a swift veto (see Catalan 1995, p. 153; San Román 1999, pp. 254-256). Shortly afterward, the regime set up the National Institute of Industry (Instituto Nacional de Industria, or INI, in Spanish), presided over

5 In 1946 the Hispano factory in Barcelona was acquired by a state agency and it turned its attention to truck production. The history of Hispano is described in Lage (2003) and Nadal (2010).

6 Ford sold its entire stake in its subsidiary to local shareholders and Ford Motor Ibérica became Motor Ibérica (Estapé 1998). 
by Juan Antonio Suanzes ${ }^{7}$. The INI was a state entity, or public holding company, fashioned after Mussolini's Institute for Industrial Reconstruction, and its purpose was to promote industrial development in Spain based on an autarkic conception of the economy. Suanzes did not hesitate to intervene directly in order to give the INI control over domestic production of motor vehicles (see Martín Aceña and Comín 1991, pp. 225-229).

Banco Urquijo and FIAT began to negotiate the transfer of technology to manufacture vehicles in Franco's Spain in early 1939, but the conversations collapsed as a result of the intrusion of Suanzes (see San Román 1995, pp. 143-149). In 1947, Banco Urquijo and FIAT reopened negotiations and once again Suanzes interfered. Emboldened by his appointment as minister for industry, he forced Banco Urquijo to accept the INI's control over the project. Finally, between July and October 1948, agreements were forged to enable FIAT to accept the granting of its licences in exchange for 12.5 million pesetas, a royalty of 3 per cent on the sale price of each vehicle and a Spanish commitment not to export.

On 9 May 1950, the Sociedad Española de Automóviles de Turismo (SEAT) was established. SEAT received numerous tax benefits as a result of its having been recognised as an enterprise of national interest. Its nominal capital was 600 million pesetas. The INI, with 51 per cent of the capital stock, was the majority shareholder. In addition, six Spanish banks, led by Banco Urquijo, each held 7 per cent of the capital stock with FIAT retaining the remaining 7 per cent. The SEAT factory was built in the Zona Franca area of the Barcelona port (see San Román 1999, pp. 236-247; Catalan 2006, pp. 144-149).

SEAT began operations in the summer of 1953 with the production of the FIAT 1400, a mid-range model. Two years later, SEAT expanded its capital stock to 900 million pesetas. The aim was to obtain production of the FIAT 600 , a low-end model more in line with the state of the Spanish market. The first units of the new vehicle were manufactured in the spring of 1957. A year later, the percentage of local parts and components incorporated in the model's production reached 97 per cent. Its success was immediate and production swiftly topped 20,000 units annually, pushing SEAT beyond the threshold for mass production (see Catalan 2006, pp. 148-153).

The company went on to experience uninterrupted growth, exceeding 50,000 cars per year in 1964 and 100,000 in 1966. In 1967, FIAT increased its stake in the company to 36 per cent, while the INI reduced its stake to a similar level. According to Catalan (2006, pp. 167-169), three factors can account for FIAT's shift: the security created by the increase in FIAT's relative clout among shareholders; the massive strikes and social unrest in Italy in 1969, which made SEAT look like a good alternative to internal Italian supplies; and the demonstrated willingness of the Spanish government to defend domestic

7 On 2 February 1938, Suanzes had been appointed minister of industry and trade in Franco's first government. Suanzes was dismissed on 11 August 1939. 
production. In short, SEAT's production capacity soared: by 1969, annual production surpassed 200,000 cars and by 1972 it exceeded 300,000.

The other company that could be called a first-mover was Fabricación de Automóviles Sociedad Anónima (FASA), founded on 29 December 1951 in Valladolid. FASA's objective was to assemble the Renault 4CV. The driving force behind the project was the then Lieutenant Colonel Manuel Jiménez-Alfaro, who was ultimately named general manager and oversaw the management of the company. In late 1950, Jiménez-Alfaro successfully concluded lengthy negotiations to gain production licences for the $4 \mathrm{CV}$. According to the agreement, the French would refrain from financial participation in the future company and gave assurances that the units produced would be distributed by their commercial subsidiary in Spain, the Sociedad Anónima Española de Automóviles Renault (SAEAR; see Sánchez Sánchez 2006, p. 353). SAEAR had been set up in 1909 and had remained completely inactive since the outbreak of the Civil War.

Now that an agreement had been reached with the French, JiménezAlfaro needed to overcome the INI's direct opposition to achieve the necessary administrative permission. To remove this hurdle, the Lieutenant Colonel offered Nicolás Franco, the dictator's brother and a former colleague of Suanzes in the naval military school, the chairmanship of the future company. Influence peddling - a highly regarded activity in Spain — was his main skill ${ }^{8}$, and administrative authorisation was obtained in October 1951. The conditions included a requirement to incorporate a percentage of domestic content in each car that would be 90 per cent by the end of the 3rd year and 100 per cent by the end of 6 years (BOE, 19 October 1951). The next step was to find the committed finance. A 100 small investors of Valladolid contributed the initial capital of 5 million pesetas and disbursed 39 of the 55 million pesetas for the immediate expansion. The remainder was covered by SAEAR (see Fernández-de-Sevilla 2010a, pp. 141-142).

The first units of the 4CV were assembled in August 1953. Following high levels of tension between the investor group in Valladolid and SAEAR, Banco Ibérico of the Fierro family purchased 10 per cent of the capital in 1954. A year later, Banco Santander acquired another 10 per cent of the shares. In this way, two leading Spanish financial institutions with strong industrial interests gained a stake in the automotive company and they shared the same interest in FASA: to link FASA's development to the development of their own industrial portfolios (see Fernández-de-Sevilla 2010a, pp. 145-150).

In mid-1955, Banco Santander became the principal shareholder of FASA. In the wake of this shift, Nicolás Franco and Manuel Jiménez-Alfaro agreed to step back and leave direct control of FASA in the hands of Eduardo Ruiz de Huidobro, Banco Santander's strong man in Valladolid. His mandate was unambiguous: to ensure the manufacture of the engines and gearboxes in Spain. Huidobro commissioned the engine from Nueva

\footnotetext{
${ }^{8}$ See Garriga's (1980) biography of Nicolás Franco.
} 
Montaña Quijano (NMQ), a company run by Banco Santander, while the production of the transmission was entrusted to Industrias Subsidiarias de Aviación, a company in the Fierro Group. Between 1958 and 1961, Banco Santander had absolute control of FASA and FASA's production stagnated in the region of 8,000 cars a year. Eventually, Banco Santander sold its stake to Banco Ibérico (see Fernández-de-Sevilla 2010a, pp. 151-153).

It was under the control of the Fierro family that FASA began mass production. Not only did production capacity rise sharply under the company's new masters, but also a process to integrate production vertically was initiated. In time, FASA took over direct manufacture of engines, gearboxes and bodywork. Banco Ibérico's sole control of FASA came to end in 1965. At that time, FASA's annual production of Renault automobiles bordered on 50,000 units, the models under production had been diversified and their rates of domestic production stood at roughly 90 per cent. As a result, the firm had become the primary centre of Renault automobile production outside France. However, efforts made to achieve integrated development revealed Banco Ibérico's lack of ability to take the project forward under its own steam. In the course of the second half of 1964, negotiations resulted in the takeover of SAEAR by FASA. At the same time, Renault acquired a majority stake in FASA that was transformed into FASA-Renault, and the Fierros became minority shareholders.

The French reorganised their new subsidiary on functional lines in order to achieve a management structure capable of making the most of their planned investment in production, marketing and distribution. The emergence of large modern enterprises in France had been characterised by their slow rate of development. The turning point in the promotion of managerial capitalism was to be the nationalisations of 1944-1948, in which that of Renault was the most significant as Patrick Fridenson (1997, p. 231) explains. According to Michel Freyssenet (1998, pp. 366-371), Renault's production model, based on volume and diversification, reached its zenith in the 1960s. As shown by Loubet (2000, pp. 140-184), at the time it acquired FASA, Renault was already a large firm that had successfully completed the three-pronged investment. Marketing and distribution capabilities were crucial in a sector marked by steadily increasing supply and a demand that had lost its impetus since the mid-1960s. The experience of Renault's sales department provided the basis for the strategy in Spain. As in France, this strategy turned on the diversification of models and the expansion of points of sale. Range and network bore fruit. In 1972, the launch of a second assembly plant enabled FASA-Renault's production to top 100,000 vehicles a year (see Fernández-de-Sevilla 2010b, pp. 480-486).

In the light of the foregoing, it seems clear that the main source of advantage lay in SEAT's ability to exploit its scale economies. The SEAT 600 was to play a leading role in the company's takeoff, representing 56 per cent of the units produced in the 1960s. By contrast, FASA-Renault's adoption of mass production was much slower, and was not consolidated until Renault 
TABLE 1

PRODUCTION AND REGISTRATION OF PASSENGER CARS IN SPAIN, 1965-1975

\begin{tabular}{|l|c|c|l|c|c|}
\hline \multicolumn{3}{|c|}{ Cumulative production } & \multicolumn{3}{c|}{ Cumulative registration } \\
\hline & Units & $\%$ & & Units & $\%$ \\
\hline SEAT & $2,679,372$ & 54.1 & SEAT & $2,331,325$ & 52.5 \\
\hline FASA & $1,125,495$ & 22.7 & Renault & $1,040,795$ & 23.3 \\
\hline Citroën Hispania & 424,947 & 8.6 & Citroën & 319,273 & 7.1 \\
\hline Barreiros Diesel & 498,743 & 10.1 & Simca & 392,145 & 8.8 \\
\hline AUTHI & 224,826 & 4.5 & Dodge & 24,994 & 0.6 \\
\hline Others & 754 & 0.0 & Morris & 135,606 & 3.0 \\
\hline & & & Remainder & 224,881 & 5.0 \\
\hline
\end{tabular}

Sources: Catalan (2000, p. 150) and Dirección General de Tráfico (1960-1985).

eventually assumed the reins of the company. The French focused their strategy on the diversification and expansion of its sales network, which ushered in good results and facilitated the construction of a second assembly factory in 1969. Thus, both companies completed their three-pronged investment during the decade of the 1960s. The chief difference between the two lay in their respective management models. While from the outset SEAT employed a model that, according to Chandler, could be defined as managerial, FASA operated a personal style of management until it became FASA-Renault. Likewise, both companies enjoyed government favour. While SEAT, recognised as an enterprise of national interest, was controlled by the INI, FASA was chaired by Nicolas Franco, whose primary business skill was that of pulling the strings of government.

As Table 1 shows, SEAT and FASA took the lead in the development of the automotive industry in Spain. The main role fell to a public company whose aggregate output represented nearly 55 per cent of all cars produced in the period. However, challengers soon appeared. The first was Citroën Hispania, which completed assembly of its first units in 1961. Close behind followed Barreiros Diesel and AUTHI, which began operations in the mid-1960s. Nevertheless, none of the challengers were able to reach the production levels of the two first-movers.

\section{THE FAILURE OF THE CHALLENGERS}

Following in Renault's wake, the Michelin family, owners of Citroën, took an interest in the possibility of production in Spain. In August 1955, Pedro 
González Bueno, a former minister and colleague of Suanzes in Franco's first government, requested permission to produce the Citroën 2CV. Permission, which came in the spring of 1956, required a minimum rate of domestic content of 60 per cent within 4 years and the annual production quota was limited to 10,000 vehicles for the Spanish market, with the remaining output necessarily destined for export (see Lebrancon 2009, p. 302). According to De la Torre (2007, p. 114), the Council of Ministers authorised the parent company to take up 45 per cent of the shares in Citroën Hispania, provided that the investment reached 100 million pesetas (a sum that doubled the initial investment) and that 80 per cent was applied to fixed assets. Once again, permission had been obtained by a man with close ties to the regime.

In September 1956, Citroën announced that the future Citroën Hispania, led by González Bueno, would be located in the Free Zone of the port of Vigo. The first cars rolled out of the plant in 1961, but it was not until 1965 that annual output exceeded 10,000 units. Despite projections, domestic demand provided the main - and practically only - market until well into the 1970s. Production figures for Citroën Hispania hovered on the threshold for mass production. The firm did not experience real development until the 1970s. Until that time, as Carmona and Nadal (2005, p. 332) show, they manufactured a single low-end model with obsolete machinery at low levels of productivity.

On 21 July 1959, the Spanish government enacted a decree-law on economic planning that served as the cornerstone of a programme of stabilisation and gradual liberalisation of the economy in response to the evident inability of the state to meet its foreign debts. Although public intervention continued under the legislation, the manifest intention was to move towards a market economy. In this direction, a decree was passed on 26 January 1963 to authorise the unrestricted set up, expansion and relocation of industries, although the state reserved the power to establish standards to be followed in accordance with the characteristics of each sector, as well as the power to guide and stimulate the creation of new enterprises and to modernise and restructure existing ones. Shortly afterwards, the state laid down the conditions by which the automotive industry was to operate. First, the minimum production capacity was set at 75,000 passenger cars a year and increased 2 years later to 125,000 passenger cars in two work shifts. Second, for new enterprises and new models, the percentages of domestic production were set at 90 per cent for the first unit produced from the 3rd year of production (BOE, 22 July 1959, 29 February 1963, 19 March 1963, 18 July 1964 and 12 January 1965).

The first initiative to spring up under the new legal framework was the company Barreiros Diesel Sociedad Anónima (Barreiros). A family firm founded in 1954 at the behest of Eduardo Barreiros Rodríguez, the new enterprise sought to manufacture diesel engines and commercial vehicles in Villaverde (Madrid), making use of Barreiros's 1951 patent for converting gasoline engines to diesel. Within a few years, Barreiros had a capital stock of 200 million pesetas. His chief source of finance was the Banco de 
Vizcaya, which took a seat on the board of directors in 1959, as a minority shareholder ${ }^{9}$.

In 1962, a financial crisis stemming from excessive sales financing left Barreiros in dire straits ${ }^{10}$. In need of a capital infusion, Eduardo Barreiros, who had already shown an interest in the manufacture of passenger cars, turned to Chrysler where he found a solution to his liking ${ }^{11}$. In December 1963, the U.S. automaker acquired 40 per cent of the company. Under the stipulations of the purchase, Barreiros would produce the high-end Dodge Dart and the mid-range Simca 1000. The projected volumes, however, were overly optimistic: forecast sales for 1966 were 21,000 units of the Dodge Dart and 62,000 units of the Simca 1000, while the actual results were 6,000 and 35,000, respectively. Before long, it became clear that Barreiros's indebtedness, compounded by new investments, had no prospect of solution.

In mid-1967, Chrysler estimated that refloating the company would require an investment in plant and distribution network in the region of 35 million U.S. dollars. Before the year-end, the Americans had taken 77.2 per cent of the shares and control of Barreiros. In 1969, Chrysler announced an increase of 2.7 billion pesetas in share capital, requiring full payment on subscription. As García Ruiz and Santos (2001, pp. 167-189) explain, this provision forced Barreiros to liquidate his stake in the company that bore his name. As a result, Barreiros Diesel became Chrysler Spain. The new company reported no profits until 1972 (see Table 2). By that time, Chrysler's stake in the company had reached 98 per cent.

The last company to emerge in the 1960s was Automóviles de Turismo Hispano Ingleses Sociedad Anónima (AUTHI). The company began to take shape in late 1964, when it became clear that FASA intended to break relations with NMQ for the provision of engines. At that time, Eduardo Ruiz de Huidobro took over the manufacturing licences for the Morris and Mini passenger cars of the British Motor Corporation. AUTHI began operations in April 1967 in a plant located near Pamplona. From the beginning, the company faced sharp constraints on its production capacity, owing to a paltry initial capital of 20 million pesetas and the refusal of its British partners to take a stake (see De la Torre 2007, p. 133). The low volume of their production runs in the first 3 years of activity reached only 15,000, 21,000 and 16,000 vehicles a year and this hampered the achievement of a minimum level of competitiveness, which left the company in an untenable position.

\footnotetext{
9 A history of the company can be found in García Ruiz and Santos (2003) and Thomas (2007).

10 Until then, Barreiros had manufactured 45,000 engines and 9,000 trucks (García Ruiz and Santos 2003, p. 192).

11 In May 1960, Barreiros had requested permission to produce high-end cars, negotiating with Aston Martin, Jaguar, Rootes and GM. However, the operation was cancelled as a result of opposition from SEAT and INI.
} 
TABLE 2

NET PROFITS BY MAKER, 1965-1973 (MILLION PESETAS OF 1965)

\begin{tabular}{|l|c|c|c|c|}
\hline & SEAT & FASA-Renault & Barreiros $^{\mathbf{1}}$ & AUTHI \\
\hline 1965 & 570 & 146 & 121 & \\
\hline 1966 & 543 & 191 & 254 & \\
\hline 1967 & 510 & 245 & -582 & \\
\hline 1968 & 436 & 231 & -225 & \\
\hline 1969 & 566 & 257 & -406 & \\
\hline 1970 & 586 & 280 & -620 & \\
\hline 1971 & 460 & 259 & -481 & \\
\hline 1972 & 643 & 299 & 25 & \\
\hline 1973 & 793 & 284 & 331 & -477 \\
\hline Total & 5,107 & 2,191 & $-1,585$ & $-2,137^{2}$ \\
\hline
\end{tabular}

Notes:

${ }^{1}$ Chrysler España since 1971.

${ }^{2}$ Losses accumulated in 1973 and 1974

Sources: SEAT (1962-1986), FASA-Renault (1951-1986), García Ruiz and Santos (2001, p. 344) for Barreiros; and ABC newspaper for AUTHI. The series are expressed with the deflator offered in Prados De La Escosura (2003, p. 567).

In 1969, after examining several options such as Ford and SEAT, the British took a 50 per cent stake in AUTHI and removed the founder from management. Shareholder equity quickly expanded by 1.387 billion pesetas, with NMQ contributing half in the form of assets (the engine plant) plus 229 million pesetas. Despite the rise in production volumes between 1970 and 1973, the new management did not succeed in turning AUTHI into a firm that was either competitive or profitable. It was no accident that every financial year closed in the red. Ultimately, the company went bankrupt in February 1975 and was absorbed by SEAT.

Doing business with the British was perhaps not a good choice. Among the advanced capitalist economies, the United Kingdom provides the most obvious example of a declining automotive sector. In 1974, British Leyland Motor Corporation (heir to Morris, Austin and Leyland), in a state of bankruptcy, had to be bailed out by the government. British producers were clearly failing to exploit scale economies, with too many low-volume models and low-volume plants with excess capacity constraining productivity and undermining profitability. As Foreman-Peck et al. (1995) showed, these factors combined with poor business strategies, under-investment stemming 
from the lack of profits, poor industrial relations characterised by constant disputes and unsound public policies ${ }^{12}$.

While Barreiros and AUTHI obtained governmental approval, the case of Industrias del Motor Sociedad Anónima (IMOSA), which was based in Vitoria-Gasteiz, followed a different course. On 6 October 1965, IMOSA requested permission to manufacture the famous Volkswagen Beetle. In competing with AUTHI, this decision appeared to be a good course of action. The Beetle became the best selling model of all time, surpassing the model $\mathrm{T}$ in $1973^{13}$. With their strategy of only one model, the Germans provided an excellent example of the exploitation of scale economies ${ }^{14}$. On 7 December, IMOSA requested provisional enrolment in the industrial registry, announcing an annual production of 125,000 units. Two days after publishing the request in the $\mathrm{BOE}$, the ministry enacted a decree that raised the minimum level for production of passenger cars for new industries to 250,000 units a year (BOE, 20 and 22 December 1965). Although IMOSA announced its willingness to reach this target by 1970, in a transparent act of cynicism the ministry dismissed IMOSA's request on the grounds that industries of limited size brought serious problems of competitiveness. To avoid fresh upheavals, the government took action a year later to add the manufacture of passenger cars to the group of industries in need of administrative permission for their establishment of facilities, their expansion or their relocation (BOE, 25 July 1967). In spite of the fact that IMOSA presented a detailed report, a budget, an economic study, an implementation plan and a document attesting to the provision of land, it was quite unable to win over the ministry.

These dynamics demonstrate how policies applied to passenger cars in the 1950s and 1960s sought to lay down conditions that would encourage the development of established firms, particularly SEAT. The result was essentially positive. The main causes of the sector's boom need to be located in the fact that the market was empty and practically closed to imports, facilitating the placement of domestic production ${ }^{15}$. In addition, the tight control of production licences enabled SEAT and FASA to take better advantage of potential economies of scale.

As Figure 1 shows, the "challenger» firms were unable to achieve their aim of wresting a sufficiently significant market share in order to permit competitive unit costs in relation to the first-movers. All the challengers presented the same characteristics, setting out with little locally controlled capital and employing a personal style of management. Neither Citroën

12 While Lazonick (1990) emphasises poor industrial relations, Dunnet (1980) and Adeney (1988) stress unsound public policies.

13 An exhaustive history of the Volkswagen Beetle can be found in Rieger (2013).

14 The strategy of Volkswagen is analysed in Tolliday (1995).

15 In 1960, Spain had one passenger car for every 105 inhabitants, while France, Great Britain and West Germany had one for every ten inhabitants. As Viñas et al. showed, in 1979, the subsector «motor vehicles» was the most heavily protected, with an effective level of 164 per cent. 
FIGURE 1

PASSENGER CAR REGISTRATIONS IN SPAIN BY MAKE, 1961-1973 (\%)

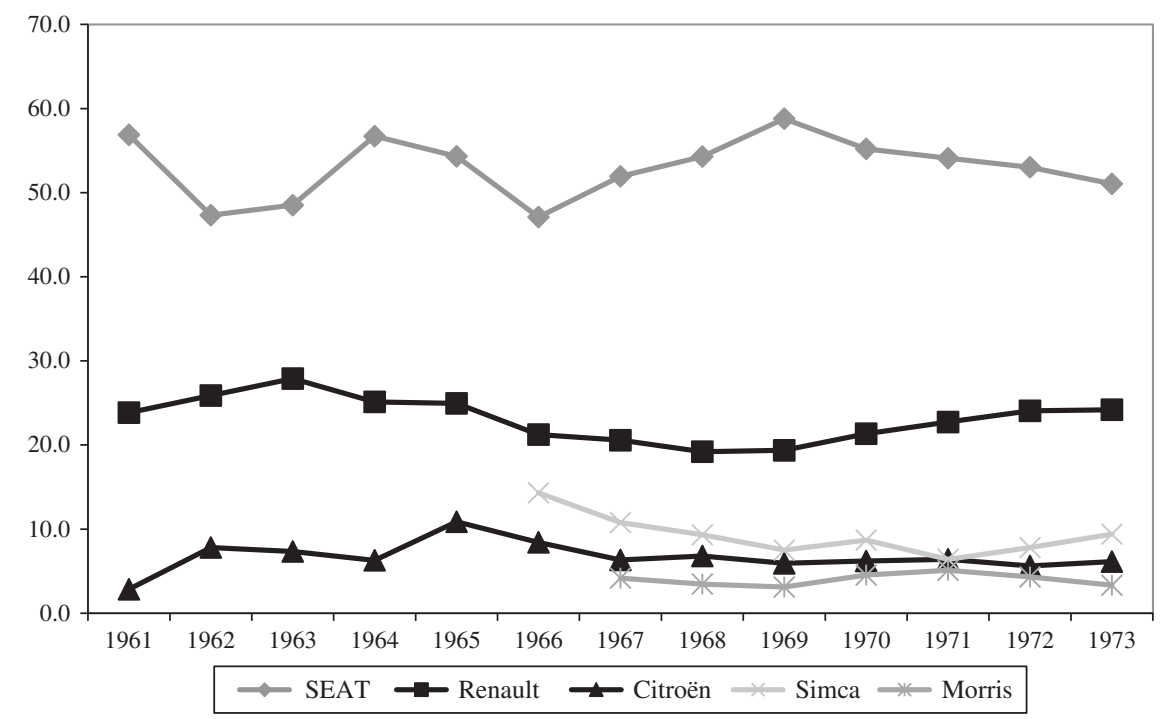

Source: Dirección General de Tráfico 1960-1985.

Hispania nor AUTHI was able to count on the help of local partners with sufficiently strong knowhow or technological partners who would genuinely commit to their development. In the case of Barreiros, despite the undeniable entrepreneurial spirit of its founder and a proven track record in the motoring world, it is clear that the company could not find a financial partner with adequate resources and it made a poor choice of technological partner.

The availability of a sufficiently robust financial partner proved crucial for challenger firms because, according to Chandler, they, unlike the firstmovers, did not enjoy the same ability to reinvest extraordinarily high profits. As Table 2 shows, the latecomers were permanently in debt. Clearly, their failure to produce profits limited their investments in production and commercialisation alike, hindering them in their attempts to compete with SEAT and FASA-Renault. Thus, as Chandler explains, the lack of a more solid financial partner can also be explained by the greater risks associated with the investment. All the latecomers ended up following the same path, being absorbed by the licensing house and adopting a managerial structure. However, as Chandler points out, this was not enough in order to be able to challenge the first-movers. When the challengers emerged, SEAT and FASA-Renault had already progressed far enough along the learning curve of 
their industry's functional activities that they could block their challengers' growth before they had the ability to develop the necessary competitive skills. Structural change in an industry like automaking, which has economies of scale that provide highly significant cost advantages, involves modifying the rules of the game.

\section{A NEW INDUSTRIAL POLICY}

In late 1972, the industrial policy applied to automaking made a $180^{\circ}$ about-face. The trigger was a preferential agreement signed between Spain and the EEC 2 years earlier. This agreement resulted in lower EEC tariffs on Spanish cars, which fell to a mere 3.3 per cent in 1974. After the agreement, Ford and GM relaunched the projects that they had abandoned with the victory of Franco's rebels: using Spain as a production platform for mid-tolow-end models aimed at the European market.

The interest displayed by the U.S. giants led to a shift in the strategic policies of the Spanish government. The chief embodiment of this shift took shape in the passage of the so-called Ford decrees of late 1972. In Decree $3339 / 1972$ of 30 November, regulating the manufacture of passenger cars, the rationale for the turnabout was put as the need to raise the competitiveness of existing manufacturers in order to increase their exports and stimulate their specialisation within the international strategy of large-scale enterprises ${ }^{16}$. However, their primary purpose was to enable Ford to set up in Spain. The conditions established for the entry of new competitors, which perfectly suited the wishes of the Americans, set the minimum local content level at 50 per cent, put the minimum threshold for investment in fixed assets at 10 billion pesetas, established the export percentage at two-thirds of unit production, pegged the value of imported pieces, parts and other components at no greater than 50 per cent of the value of the exported cars, and limited sales in the domestic market to 10 per cent of total sales in the previous year (BOE, 7 December 1972). In fact, during these years, labour costs in Spain's car industry remained lower than those in their main West European counterparts. However, the purchase costs of raw materials, parts and components (representing about two-thirds of total costs) were higher ${ }^{17}$. Thus, the reduction in the local content share substantially increased Ford's competitiveness.

The second Ford decree, enacted on 23 December, declared the sector of preferential interest with the aim of stimulating the investments needed for

${ }^{16}$ Although previous local content levels were maintained, the decree authorised a minimum of 50 per cent when the value of imported pieces, parts and components did not exceed 50 per cent of the value of automobiles exported.

17 The final cost per unit was 25 per cent lower than the average EEC cost (FASA-Renault 1976). 
the private initiative to expand exports and ramp up plant capacity and production by model. The declaration included incentives for land expropriation in order to establish or expand plants, tax reductions of up to 95 per cent, and freedom to depreciate new plant and equipment during the first 5 years. For any company to take advantage of these benefits, it needed to fulfil the following conditions within 4 years: an average production rate of greater than 500 vehicles per day; mass production greater than 400 units per day for a basic model or greater than 200 for two models; gross investment in fixed assets greater than 7 billion pesetas, and minimum annual exports at 20 per cent of production (BOE, 29 January 1973).

This policy was reaffirmed in April 1979 with the enactment of Royal Decree 816/1979 governing the organisation of the sector. Behind the new law was the view that the industry established in Spain could not remain aloof from the growing international integration that was taking place or ignore the substantial investments being made in industrial restructuring and in the expansion of production capacity that went hand in hand with restructuring. This forced a new flexibility in the regime's approaches to production, leading to a relaxation in access to the domestic market and a gradual reduction in the levels of local content so that, in the medium term, the industrial schemes would converge between manufacturers established before and after 1972 .

Along these lines, manufacturers in existence before 1972 were permitted to lower their level of local content gradually to a minimum of 60 per cent in 1984. In addition, the export values of finished vehicles and of the components of the manufacturer and its subsidiaries were required to exceed by 20 per cent the import values of vehicles and components. For automakers arriving after 1972, their overall local content level was set at 55 per cent, their export values of finished vehicles and components needed to exceed the value of their imports by 50 per cent, and their minimum exports of finished vehicles was set at two-thirds of annual unit production. Lastly, this latter group was required to meet a minimum capacity of 600 units per day and their maximum sales were fixed at 10 per cent of the total number of units registered in the previous year, until 1 January 1983, when this constraint would elapse. These conditions suited GM's wishes perfectly, to the point that Opel manufactured its first cars in 1983.

In 1974, shortly after sanctioning the shift in the strategy governing industrial policy, the Spanish economy received the first shocks of a deep recession from which it would not emerge until 1985. Spain's difficulties were the result of the crisis spreading through the economies of the West. While the first signs of deterioration had appeared in the late 1960s, recession hit in 1974 and did not relent until 1983 in most industrialised nations. However, its impact in Spain was deeper and more long-lasting. According to Rojo (1994), the reasons for this lay in a weaker energy base, a weaker industrial structure and the greater weight of the affected sectors, and these 
factors were compounded by the amassed rigidities of 30 years of dictatorship and the beginning of political reforms that demanded less strict adjustment policies.

Since the application of the national Stabilisation Plan, the Spanish economy had experienced extremely high annual growth rates (8 per cent on average), which plummeted from 1974 onwards. Until 1978, however, public spending continued to grow between 4 and 5 per cent a year. The contraction in growth was sharply compounded by inflation, which began to skyrocket in 1974 and reached a maximum of 24.7 per cent in 1977. Measures were applied to combat the threat and the climb was slowed, but the rate of inflation did not drop below 15 per cent until 1981 and it was not until 1986 that the rate fell below 10 per cent. In turn, the adjustment policies caused a sharp contraction of economic growth, with annual growth rates sinking below 1.5 per cent until the year that Spain joined the European Community, and actually falling into the red in 1981. An immediate consequence was a slump in investment, which translated into a sharp decline in employment and the appearance of high unemployment rates that topped 10 per cent, starting in $1980^{18}$.

The fall in wages caused internal demand to drop; this had a particularly strong effect on durable consumer goods, such as cars. The registration of passenger cars contracted dramatically from 1977 and hit bottom in 1981, falling to a level similar to 1972. However, despite the harsh impact of the crisis, the production of passenger cars in 1986 was double the level of 1972. The combination of production and registration figures in Spain, shown in Figure 2, is a very clear illustration of how the sector's growth necessarily had to be sustained through high levels of exports.

\section{INDUSTRY RESTRUCTURING}

With Ford's return to Spain, the U.S. giant gained access to the only large European market where it had no presence. In addition, Ford achieved its objective of using the peninsula as an export platform for mid-to-low-end passenger cars aimed at Europe. Not only did Ford obtain legislation perfectly suited to its interest, but it also benefited from numerous incentives from the public administrations in the form of prices for land and other types of financial assistance. According to Pérez Sanchó (2003, pp. 131-143), Ford set up where it wanted, imposing its conditions and relying on public agents simply to obtain the resources needed and in the best possible conditions. In addition, as Catalan (2011a, p. 108) explains, the CEO of Ford España was Claudio Boada, INI's president in the early 1970s. Ford built its industrial complex in Valencia. The production of HCS engines began in 1975 and cars

18 Between 1977 and 1985, the employed population fell from 12.8 to 10.6 million people, increasing the unemployment rate to 21.9 per cent (Carreras and Tafunell 2004, p. 367). 
FIGURE 2

PASSENGER CARS PRODUCED AND REGISTERED IN SPAIN (UNITS)

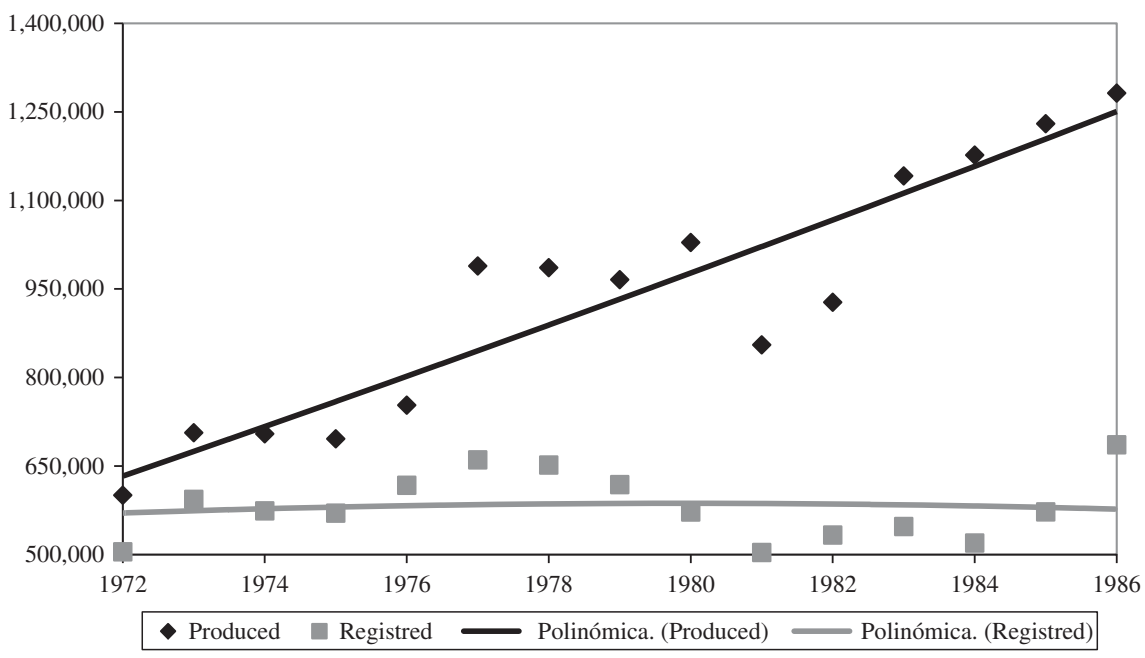

Source: ANFAC (1977-2002).

came on line a year later. The Fiesta was the only model until 1981, when production was diversified with the Escort. The sales of the Fiesta in Spain reached a high of 76,000 units in 1979, with 11 per cent market share, and then steadily declined to 26,000 in 1986, with 4 per cent market share. However, the Fiesta was chiefly for export: West Germany, France and Great Britain absorbed practically all of its sales abroad, which reached a high of 209,000 units in 1980 .

After several unsuccessful attempts, new negotiations began in 1977 and led to the passage of Decree 816/1979, tailor-made to suit GM. GM built a plant in Figueruelas (Zaragoza) and formed the company GM Spain, whose shares were owned by the GM parent company (73.5 per cent) and by Opel, GM's German subsidiary. The company's interest in the peninsula needs to be seen as comparable with the interest of Ford: to widen the range of models by adding a car at the mid-to-low end. For 20 years, GM Spain's factory specialised in manufacturing the Opel Corsa, which first came off the production line in August 1982 and had a production capacity of 1,200 units per day with two work shifts. In 1983, annual production of the Corsa hit 245,000 units and rose to 275,000 units in 1985 . The focus of this activity was clearly for export and its chief markets were West Germany, Great Britain and France ${ }^{19}$.

19 The history of Opel Spain can be found in German (2003). 
SEAT's share of the industry's overall production declined continuously during the period, falling from 50 per cent in 1973 to 18 per cent in 1985. In April 1973, shortly after Ford received the green light to enter Spain, the Spanish government contacted GM for the company to absorb AUTHI, which was going through a dramatic crisis with its results. To fend off the establishment of another U.S. automaker, SEAT expressed a willingness to take on the acquisition. AUTHI had three activities: the production of vehicles in Navarre, engine manufacture in Cantabria and the fabrication of seats in Santpedor (Barcelona). In 1969, FIAT had already stated its firm opposition to purchasing AUTHI. Now it agreed to acquire the assembly plant, but maintained its refusal to purchase the engine factory (see Catalan 2007, pp. 153-162).

In March 1975, SEAT, backed by public financial assistance, acquired the assembly plant for 1.1 billion pesetas. In a context of unmistakable recession and clear over-capacity, these purchases pushed SEAT to close the 1976 financial year in the red for the first time and the company would not turn a profit again until 1988. The situation of uncontrolled losses led the INI to propose the full takeover of the company to FIAT. In June 1979, the first agreement was signed by which the Italians made a commitment to push through a restructuring plan. In the middle of negotiations, however, the Spanish government cleared the way for Opel's entry. As Catalan showed (2007, pp. 165-167), the inconsistency of the government, compounded by the magnitude of the losses, caused the Italians to relinquish their presence in Spain. In May 1981, FIAT transferred all of its shares in SEAT to the INI.

A year later, the public holding company signed an initial agreement with Volkswagen that stipulated that SEAT would manufacture roughly 120,000 units of German vehicles a year. In addition, the agreement established that 50,000 units of the Volkswagen Polo would be exported each year in exchange for Volkswagen's use of SEAT sales network in Spain. The state's assumption of a large amount of the losses (198 billion pesetas amassed between 1978 and 1985) led to gradual increases in share capital overseen by the INI ( 80 billion pesetas in total), which were added to substantial levels of direct subsidies from the INI (110 billion pesetas) and the state's assumption of debt amounting to 185 billion pesetas (see Martín Aceña and Comín 1991, pp. 165-167; Catalan 2011b, pp 260-266). SEAT began to recover with the launch of the Ibiza model in 1984. Once SEAT had returned to health, the Spanish government of socialist Felipe González privatised the company, which embarked on a new period in its history as the third make of the Volkswagen Group.

In the case of FASA-Renault, the company entered the period in serious turmoil, but its evolution was much more successful than that of the publicly owned SEAT. The Renault subsidiary experienced losses for the first time in 1974 and went on to record losses for 2 more years as a consequence of serious industrial disputes. An initial consequence was the suspension of its development programme, which aimed primarily at increasing the 
FIGURE 3

REGISTRATION OF PASSENGER CARS IN SPAIN BY MAKE (\%)

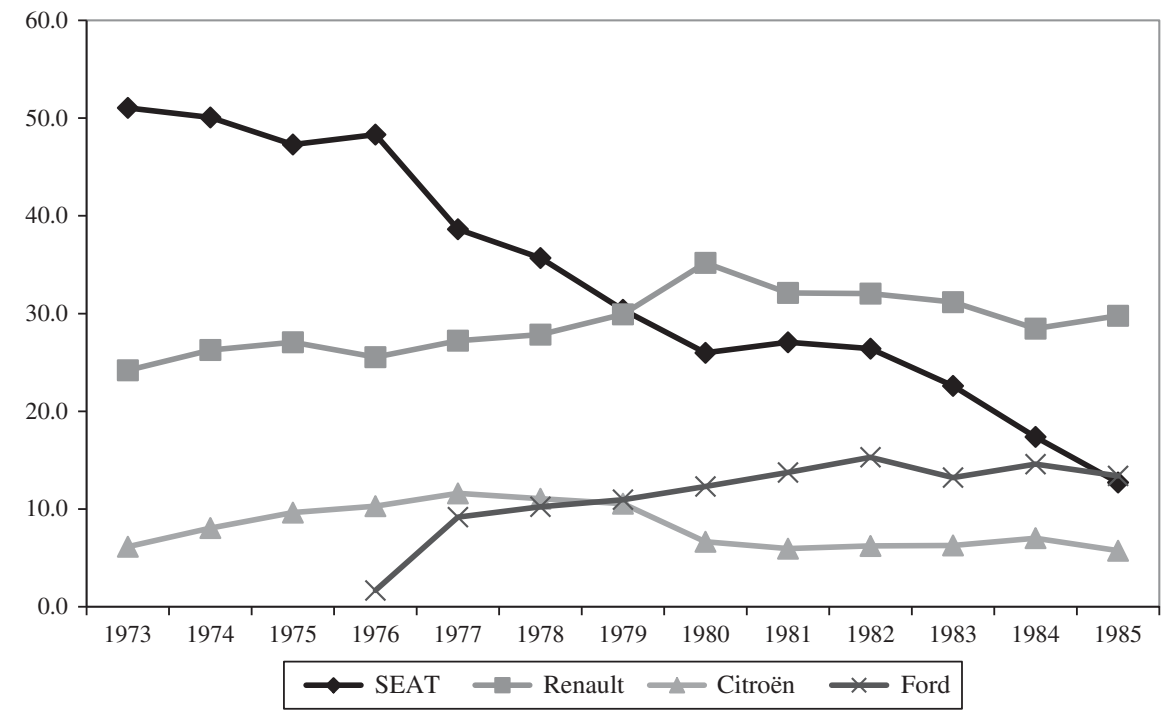

Source: Dirección General de Tráfico 1960-1985.

company's production capacity through the construction of a third assembly plant. As a result, the production level stagnated in a period when the demand for Renault models was clearly undergoing a boom. By mid-1976, the company achieved stability and this enabled it to salvage its expansion plans. With its third plant in Palencia entering into operation, FASA-Renault soon became the leading firm in the sector. The increase in production, which rose from little more than 200,000 cars in 1976 to nearly 350,000 in 1980, took place in the worst years of the economic crisis. This development was possible because of the excellent performance of domestic sales and export sales, which stood at roughly 100,000 units in 1980. The primary and practically the only client was Renault itself, which took on the job of redistributing the Spanish cars across Europe from its offices in France. Figure 3 illustrates how slight increases in domestic sales in a market in contraction enabled Renault to account for approximately a third of all registrations in 1980, turning it into the leading make in Spain. These results can largely be put down to the market's excellent response to the Renault 5, a model in the mid-to-low range that perfectly suited the circumstances at the time.

In this second phase, SEAT and FASA-Renault could do little more than maintain their market share and profits, adapting their managerial capabilities to changes in their environment. Their respective trajectories are 
TABLE 3

NET PROFITS BY MAKER, 1974-1986 (MILLION PESETAS OF 1974)

\begin{tabular}{|l|r|r|r|r|r|}
\hline SEAT & $\begin{array}{c}\text { FASA- } \\
\text { Renault }\end{array}$ & $\begin{array}{c}\text { Citroën } \\
\text { Hispania }\end{array}$ & $\begin{array}{c}\text { Chrysler } \\
\text { España }^{1}\end{array}$ & Ford \\
\hline 1974 & 373 & -127 & 154 & 683 & \\
\hline 1975 & 54 & -288 & 151 & 437 & \\
\hline 1976 & -342 & -519 & 191 & 145 & -608 \\
\hline 1977 & 248 & 950 & 960 & 434 & 46 \\
\hline 1978 & $-5,264$ & 488 & 104 & 495 & 467 \\
\hline 1979 & $-6,665$ & 1,128 & 284 & -38 & 117 \\
\hline 1980 & $-7,913$ & 1,465 & -17 & $-1,880$ & 173 \\
\hline 1981 & $-7,024$ & 1,225 & -266 & $-3,313$ & 2,262 \\
\hline 1982 & $-7,247$ & 4,249 & -532 & $-3,962$ & 2,551 \\
\hline 1983 & $-9,894$ & 3,084 & $-1,222$ & $-2,288$ & 940 \\
\hline 1984 & $-9,037$ & 103 & $-1,344$ & $-1,318$ & 3,019 \\
\hline 1985 & $-8,456$ & 16 & -25 & -114 & 2,264 \\
\hline 1986 & $-5,831$ & 3,992 & 646 & 431 & 4,181 \\
\hline Total & $-66,998$ & 15,766 & -915 & $-10,288$ & 15,413 \\
\hline
\end{tabular}

Note:

${ }^{1}$ Automoviles Talbot since 1980 .

Sources: SEAT (1962-1986), FASA-Renault (1951-1986), Citroën Hispania (1973, 1983), ABC newspaper for Chrysler/Talbot; and Oltra (2008) for Ford. The series are expressed with the deflator offered in Prados De La Escosura (2003, p. 567).

indicative of a somewhat uneven performance. While SEAT accumulated huge losses, and lost market share year-on-year; FASA-Renault made massive profits, consolidating its position as a leader in Spain. As Table 3 shows, of those enterprises established before 1972, only FASA-Renault was capable of maintaining its profits, suggesting that SEAT failed to develop its managerial capabilities. By contrast, FASA-Renault was able to develop its functional capacities and to adapt its strategies to an evolving industry, which, in line with Chandler, accounts for its success in the long term. Ford and Opel, meanwhile, both sought to compete in European markets, where they rapidly increased their net profits, maintaining positive outcomes until at least the end of the century ${ }^{20}$. Since the mid-1970s, the growth of the car

${ }^{20}$ Ford had losses in 1993 and 1998. 
industry formed part of the general strategy of the large firms to use Spain as an export platform to Europe, with the scale economies remaining at the core of this process.

The last large business group with a presence in Spain is PSA Peugeot Citroën. In 1973, Citroën took control of its Spanish subsidiary. One year later, the Michelin family offered to sell its automotive subsidiary to Peugeot. The new group, with Peugeot as the majority shareholder, was formed on 30 September 1976. For Peugeot, one of the most positive aspects of the operation was the consolidation of its position in Europe, particularly the ability to enter Spain. Despite the fact that the changes occurring in 1973, namely the divestment of shares by the group affiliated to González Bueno, had strengthened the position of Citroën Hispania, the impetus given by the French was quite weak in comparative terms.

Achieving economies of scale was one of the central pillars of the PSA strategy. According to Loubet (1998, pp. 345-347), the French sought to increase the volume of runs by integrating the various plants in a new division of labour. From 1977, the plant in Vigo began the joint production of Citroën models (GS and CX) and Peugeot models (504 and 505), embarking on a process of diversifying its supply ${ }^{21}$. However, the incorporation of the Spanish plant in these synergies made slow progress and it did not achieve full consolidation until the second half of the 1990s. In addition, the production levels that were attained did not compare with those of the remaining manufacturers in the sector.

In August 1978, PSA's acquisition of Chrysler Europe resulted in the creation of its third automotive subsidiary, Talbot, which grew out of the merger of Simca (Chrysler France), Rootes (Chrysler UK) and Chrysler Spain. In that year, the production of the former Barreiros reached 99,000 units. However, 12 months later, its output had contracted by 33 per cent, beginning a period of continuous decline that lasted 5 years. This decline ran in parallel with the decline experienced by Talbot at the European level ${ }^{22}$. The situation did not begin to right itself until 1983, when PSA took the decision to modernise its Spanish facilities by opening a manufacturing line for Peugeot XUD diesel engines and another for BE1 gearboxes. The final impetus came a year later with the start of production of the Peugeot 205, which pushed output over 100,000 units in 1986. Once again, another firm in the sector found its salvation in the production of mid-to-low-end passenger cars. Thus, both Citroën Hispania and Talbot had to wait until 1986 to see their bottom line back in the black (see Table 3).

Since the mid-1970s, international groups have used the Iberian Peninsula as a platform to export to Europe. Spain's competitiveness was based on its

${ }^{21}$ In 1983, PSA had a 68 per cent stake in Citroën Hispania, 51 per cent in the hands of Citroën SA and 17 per cent in the hands of Automobiles Peugeot SA (Citroën Hispania 1983).

${ }^{22}$ In 1984, PSA decided to remove Talbot as its third brand. The reasons were the inconsistencies with Peugeot and the collapse of its sales in France (Loubet 1998). 
labour costs and strengthened by a supply of cheap industrial land ${ }^{23}$, which accounts for the greenfield locations of Ford and GM in Valencia and Zaragoza $^{24}$. The main EEC markets absorbed Spain's large volume of exports and now the country's gradual integration into Europe was essential in sustaining the growth of the car industry, with its scale economies acting as the driving force.

\section{CONCLUSIONS}

As Chandler argues, economies of scale allowed the first-movers to establish a high barrier of entry that thwarted the development of their challengers. Two companies, founded in the middle of the century, enjoyed brilliant trajectories in the 1950s and 1960s: the rise of SEAT was based on the exploitation of scale economies derived from the success of the SEAT 600, a mid-to-low range model; while the takeoff of FASA-Renault in the early 1960s took place as a result of the French acquisition of the former FASA. Renault successfully boosted its new Spanish subsidiary through a three-pronged investment plan: expanding and modernising its production facilities; completely reforming its marketing and distribution network in line with its commercial capabilities in its ongoing competitive struggle in France; and modifying its directive hierarchy with its managerial and organisational capabilities being promoted on the other side of the Pyrenees. Thus, SEAT and FASA-Renault both successfully leveraged their competitive advantage as first-movers.

By contrast, the firms that challenged their position did not succeed in their push to grab a sufficiently large market share to achieve competitive unit costs. Neither Citroën Hispania nor AUTHI enjoyed the assistance of local stakeholders with sufficient knowhow or a technology partner to make a genuine commitment to its development. In the case of Barreiros, despite the undoubted business spirit of its founder and a proven track record in the motoring world, the company plainly lacked a financial partner with adequate resources and it made a poor choice of technological partner. The evidence provided shows that latecomers were unable to obtain either sufficient market share or sufficient net profits to challenge the positions of SEAT and FASA-Renault. This lack of profitability undermined their capacity for self-investment, demonstrating their shortfall in financial and technological knowhow.

23 One of the main incentives for Ford and GM in the legislation was that of land prices.

24 However, industrial relations do not appear to have been any more stable than they were in countries such as the United Kingdom or Italy. In the face of a declining dictatorship, the country's car plants were one of the bastions of opposition to the Franco regime. All Spanish factories were typified by major industrial disputes, which combined labour and political friction. See Tappi (2008) for SEAT; Charron (1998) for FASA-Renault; and Iriarte (1995) for AUTHI. 
The evidence presented appears to confirm the conclusions drawn by Binda (2012) that Spain's large manufacturing firms shaped their strategies and structures based not solely on economic facts, but also in relation to the political and social context, pointing to the importance of such factors as delayed industrialisation and state intervention. The dynamics of the Spanish auto industry confirm that policies to promote industrialisation played a key role in the takeoff of the mass production of passenger cars. Until the mid-1970s, the implemented policies remained very constant: reserving the market for domestic production, maintaining strict control over the number of manufacturers and requiring a high degree of domestic content. The closure of the market led to practically all of the domestic supply finding buyers. The limitation on the number of manufacturers favoured the utilisation of economies of scale. The high local content requirements increased firm size. During these years, domestic demand was the driving force behind sector growth, while the availability of a relatively abundant cheap labour supply was not a significant factor in the decisionmaking process of multinational firms that opted to transfer their technology. The companies transferring technology always did so with the intention of taking advantage of the growth phase of an average-sized market that had low levels of motorisation and was protected by high external tariffs.

The enactment of the Ford decrees marked a break with the policies applied in the previous 2 decades. No longer viewing the domestic market as the driving force or requiring the production of components internally, the policy shifted towards a commitment to foreign markets as the primary agents of future development and towards lower requirements on domestic production. The enactment of the 1979 decree reaffirmed this policy and paved the way for the liberalisation of imports of components and finished vehicles. Both Ford and Opel directed the bulk of their production towards the EEC, creating a new structure in the sector. Since the mid-1970s, the trajectory of SEAT suggests that it failed to develop its managerial capabilities, losing market share and profits in the process. By contrast, FASA-Renault was able to develop its functional capacities and to adapt its strategies to an evolving industry, which accounts for its success in the long term, in keeping with Chandler's point of view. In this period, the growth of the car industry formed part of the general strategy of the large firms to use Spain as an export platform to Europe, with the scale economies remaining at the core of this process. The restructuring of the sector shaped the new role that Spain was to play in the automotive industry as a producer specialising in mid-to-low-end models aimed at Europe.

The evidence presented also shows how the ability to control and pull the strings of government constituted one of the industry's core competencies throughout the period. While SEAT was a public company, the presidents of FASA and Citroën Hispania were, respectively, General Franco's brother and a former minister in his first cabinet. In the 1970s, the negotiations conducted 
by Henry Ford II with the Ministry of Industry culminated in the enactment of the decrees of 1972, which granted the Americans their main requests. Not only were these decrees referred to as the "Ford decrees», but the president of Ford España was Claudio Boada, INI's president in 1972. Similarly, GM also secured legislation that was completely adapted to the company's interests.

The firms established before the legislative changes of 1972 were founded predominantly with Spanish capital and operated a personal style of management, with the exception of SEAT, which operated a managerial model from the outset. By contrast, in 1985 all the firms were under the control of large international groups and operated a managerial model. Thus, although it was not until the 1980s that the structure of the automotive industry in Spain could be fully defined within the model of competitive managerial capitalism described by Chandler, its dynamics indicate that from the mid-1960s on this was the direction in which it was evolving.

\section{REFERENCES}

Adeney, M. (1988): The Motor Makers: The Turbulent History of Britain's Car Industry. London: Fontana/Collins.

AматоRI, F. (1997): «Reflections on Global Business and Modern Italian Enterprise by a 'Stubborn Chandlerian'». Business History Review 71 (2), pp. 309-318.

ANFAC (2002): Anfac 1977-2002. Madrid: ANFAC.

Asociación Nacional de Fabricantes de Automóviles y Caminones (1990-2010): Memorias Anuales. Madrid: ANFAC.

Binda, V. (2012): «Strategy and Structure in Large Italian and Spanish Firms, 19502002». Business History Review 86 (3), pp. 503-525.

Boe (1939-1979): Boletín Oficial del Estado. Madrid: BOE.

Carmona, X., and Nadal, J. (2005): El empeño industrial de Galicia. 250 años de historia, 1975-2000. A Coruña: Fundación Pedro Barrié de la Maza.

Carreras, A., and Tafunell, X. (1997): «Spain: Big Manufacturing Firms Between State and Market, 1917-1990», in A. Chandler et al. (eds), Big Business and the Wealth of Nations. Cambridge: Cambridge University Press, pp. 277-304.

CARRERAS, A., and TAFunell, X. (2004): Historia económica de la España contemporánea. Barcelona: Crítica.

Catalan, J. (1995): La economía española y la Segunda Guerra Mundial. Barcelona: Ariel.

Catalan, J. (2000): «La creación de la ventaja comparativa en la industria automovilística española, 1898-1996». Revista de Historia Industrial 18, pp. 113-155.

Catalan, J. (2006): «La SEAT del desarrollo, 1948-1972». Revista de Historia Industrial 30, pp. 143-193.

Catalan, J. (2007): «La primera crisis de SEAT: el veto a General Motors y la compra de AUTHI a British Leyland (1972-1976)». Investigaciones de Historia Económica 9, pp. 141-172.

Catalan, J. (2010): «Strategic Policy Revisited: The Origins of Mass Production in the Motor Industry of Argentina, Korea and Spain, 1945-87». Business History 52 (2), pp. 207-230.

Catalan, J. (2011a): «Los cuatro franquismos económicos, 1939-77», in S. Cruz, and J. Ponche (eds), El mundo del trabajo en la conquista de las libertades. Jaén: Universidad de Jaén, pp. 55-112. 
Catalan, J. (2011b): «La SEAT del Ibiza, 1981-2010: fuerza de una marca, resistencia de un distrito", in J. Catalan et al. (eds), Distritos y clusters en el sur de Europa. Madrid: LID, pp. 259-316.

Catalan, J., and Fernández-De-Sevilla, T. (2013): «Die staatliche Industriepolitik und die Entwicklung der Automobilindustrie in Spanien 1948-1985», in S. Tilly, and F. Triebel (eds), Automobilindustrie 1945-2000. Eine Schlüsselindustrie zwischen Boom und Krise. München: Oldenbourg, pp. 255-284.

Chandler, A. (1962): Strategy and Structure: Chapters in the History of the American Industrial Enterprise. Frederik, MD: Beard Books.

Chandler, A. (1977): The Visible Hand: The Managerial Revolution in American Business. Cambridge, MA: Harvard University Press.

Chandler, A. (1990): Scale and Scope. The Dynamics of Industrial Capitalism. Cambridge, MA: Harvard University Press.

Chandler, A. (1992): «Organizational Capabilities and the Economic History of the Industrial Enterprise». Journal of Economic Perspectives 6(3), pp. 79-100.

Charron, E. (1998): «FASA-Renault: Innovation in Productive Flexibility and Job Security», in R. Boyer, E. Charron, U. Jürgens, and S. Tolliday (eds), Between Imitation and Innovation. The transfer and Hybridization of Productive Models in the International Automobile Industry. Oxford: Oxford UP, pp. 254-277.

CitroËn Hispania (1973-1983): Memorias. Vigo: Citroën Hispania.

Comín, F., and Martín Aceña, P. (eds), (1996): La empresa en la historia de España. Madrid: Cívitas.

DE LA TORRE, J. (2007): «Industria del automóvil y desarrollo económico regional: la experiencia de Navarra (1955-1980)». Investigaciones de Historia Económica 9, pp. 109-140.

Dirección General De Tráfico (1960-1985): Anuario Estadístico General. Madrid: DGT.

Drucker, P. (1946): The Concept of the Corporation. New York: John Day.

Dunnetr, P. (1980): The Decline of the British Motor Industry: The Effects of Government Policy, 1945-1979. London: Croom Helm.

Estapé, S. (1998): «Economic Nationalism, State Intervention and Foreign Multinationals: The Spanish Ford Subsidiary, 1920-1954». Essays in Economic and Business History XVI, pp. 75-93.

Fasa-Renault (1976): «Acta de la Junta General, 22 June 1976». Madrid: FASA-Renault.

Fasa-Renault (1951-1986): Memorias de actividad. Madrid: FASA-Renault.

Fernández-De-Sevilla, T. (2010a): «Industrializando la España interior. El montaje del Renault 4CV en la FASA de Valladolid, 1951-1958». Investigaciones de Historia Económica 18, pp. 133-162.

Fernández-De-Sevilla, T. (2010b): «Renault in Spain: From Assembly to Manufacture, 1961-72». Business History 52 (3), pp. 471-492.

Foreman-Peck, J.; Boden, S., and Mckinlay, A. (1995): The British Motor Industry. Manchester: Manchester University Press.

Foreman-Peck, J., and Hannah, L. (2012): «Extreme Divorce: The Managerial Revolution in UK Companies Before 1914». Economic History Review 65 (4), pp. 1217-1238.

Freyssenet, M. (1998): «Renault: From Diversified Mass Production to Innovative Flexible Production", in M. Freyssenet et al. (eds), One Best Way? Trajectories and Industrial Models of the World's Automobile Producers. Oxford: Oxford University Press, pp. 365-394.

Fridenson, Patrick (1997): «France: The Relatively Slow Development of Big Business in the Twentieth Century», in A. Chandler et al. (eds), Big Business and the Wealth of Nations. Cambridge: Cambridge University Press, pp. 207-245. 
García Ruiz, J. L. (2001): «La evolución de la industria automovilística española, 19461999: una perspectiva comparada». Revista de Historia Industrial 19-20, pp. 133-163.

García Ruiz, J. L., and Santos, M. (2001): ¡Es un motor español! Historia empresarial de Barreiros. Madrid: Síntesis.

Garriga, R. (1980): Nicolás Franco: el hermano brujo. Barcelona: Planeta.

German, L. (2003): «Made in GM. Veinte años de Opel en España (1982-2002)», in J. L. García Ruiz (ed.), Sobre ruedas. Una historia crítica de la industria del automóvil en España. Madrid: Síntesis, pp. 167-190.

Hannah, L. (1995): "The American Miracle, 1875-1950, and After: A View in the European Mirror». Business and Economic History 24 (2), pp. 197-220.

IrIarte, J. (1995): Movimiento obrero en Navarra (1967-1977). Pamplona: Gobierno de Navarra.

Lage, M. (2003): Hispano Suiza 1904-1972. Hombres, empresas, motores y aviones. Madrid: LID.

Lazonick, W. (1990): Competitive Advantage on the Shop Floor. Cambridge, MA: Harvard University Press.

LEBRANCón, J. (2009): «El recinto aislado. La zona franca de Vigo y las franquicias arancelarias en España desde 1850 hasta la adhesión a la CEE». PhD dissertation, Santiago de Compostela Universidade de Santiago de Compostela.

Loubet, J. (1998): «Peugeot Meets Ford, Sloan, and Toyota», in M. Freyssenet et al. (eds), One Best Way? Trajectories and Industrial Models of the World's Automobile Producers. Oxford: Oxford University Press, pp. 338-364.

Loubet, J. (2000): Renault. Histoire d'une Enterprise. Boulogne-Billancourt: ETAI.

Martín Aceña, P., and Comín, F. (1991): INI. Cincuenta años de industrialización en España. Madrid: Espasa-Calpe.

Nadal, J. (2010): «Cerimònia Acadèmica d'Investidura com a Doctor Honoris Causa del profesor Jordi Nadal». Discurs d'acceptació del títol de doctor honoris causa, Universitat Pompeu Fabra, Barcelona.

Oltra, J. (2008): «Les entranyes de la Ford. Anàlisi de l'empresa Ford España, 19762006», Papers d'Història de Catalunya, Universitat de Barcelona.

PÉrez SANChó, M. (2003): «La industria del automóvil en la Comunidad Valenciana: el caso de Ford España», in J. L. García Ruiz (ed.), Sobre ruedas. Una historia crítica de la industria del automóvil en España. Madrid: Síntesis, pp. 127-166.

Prados De La Escosura, L. (2003): El progreso económico de España, 1850-2000. Madrid: Fundación BBVA.

Rieger, B. (2013): The People's Car. A Global History of the Volkswagen Beetle. Cambridge, MA: Harvard University Press.

Rojo, L. A. (1994): «La Crisis de la Economía Española, 1973-1984», in J. Nadal et al. (eds), La economía española en el siglo XX. Una Perspectiva Histórica. Barcelona: Ariel, pp. 190-200.

SAN Román, E. (1995): «El nacimiento de la SEAT: autarquía e intervención del INI». Revista de Historia Industrial 7, pp. 141-165.

SAN Román, E. (1999): Ejercito e industria: el nacimiento del INI. Barcelona: Crítica.

SÁnchez Sánchez, E. (2006): Rumbo al sur: Francia y la España del desarrollo, 1958-1969. Madrid: CSIC.

SCRANTON, P. (1997): Endless Novelty: Specialty Production and American Industrialization, 1865-1925. Princeton, NJ: Princeton University Press.

SEAT (1962-1986): Memorias y balances. Barcelona: SEAT.

Supple, B. (1991): «Scale and Scope: Alfred Chandler and the Dynamics of Industrial Capitalism». Economic History Review 14 (3), pp. 500-514. 
TAPPI, A. (2008): Un'impresa italiana nella Spagna di Franco. Perugia: CRACE.

Tномаs, H. (2007): Barreiros. El motor de España. Madrid: Planeta.

Tolliday, S. (1995): «Enterprise and State in the West German Wirtschaftswunder: Volkswagen and the Automobile Industry, 1939-1962». Business History Review 69 (3), pp. 273-350.

Valdaliso, J. M., and LóPez, S. (2000): Historia económica de la empresa. Barcelona: Crítica.

Viñas, A.; Viñuela, J.; Eguidazu, F.; Pulgar, C., and Florensa, S. (1979): Política comercial exterior en España (1931-1975). Volumen 2. Madrid: Banco Exterior de España.

WiLkins, M. (2008): "Chandler and Global Business». Business History Review 82 (2), pp. 251-266.

Womack, J. P.; Jones, D. T., and Roos, D. (1990): The Machine That Changed the World. New York: Simon \& Schuster. 